\title{
構造最道化問題に対する進化的 L システムの有効性 Validity of the Evolutionary L-systems for the structural optimization problems
}

\author{
正 尾田 十八（金沢大） \\ ○学 山本 照晃 (金沢大) \\ 学 宮西 润（金沢大院）
}

Juhachi ODA, Kanazawa University, 2-40-20, Kodatsuno, kanazawa

Jun MIYANISHI, Graduate school of Natural Science, Kanazawa University

Teruaki YAMAMOTO, Student at Kanazawa University

Key Words : Computational Mechanics, Optimum Design, L-system, Genetic Algorithm

\section{1. 緒言}

目的に応じた最適構造を創生する為に，様々な手法が提案 されている．その中の 1 つである遭伝的アルコリズム(G A) は生物進化のメカニズムを模做した最適化手法であるが, 問 題によってはコーディングの限界から最適解を得ることが困 難な場合もある。

このような点から L システム ( L S ) と GAを組み合わせ, あたかも生物が生長するように目的に応じた最適構造を創生 する手法である進化的Lシステム (E L S)が提案された (1). 本研究ではこの手法に対して, 目的に応じた最適構造を勃率 よく得るために手法中の各パラメータをどのように設定すれ ばよいかについて考察する.

\section{2. 進化的Lシステムについて}

2. 1 Lシステムについて

2. 1. 1 Lシステムの基本バラメータ(2)

L S は細胞の分裂增殖によって生物の形態の発生を記述す る概念を中心とした形態発生システムである。その中心をな すものは発生過程に登場する細胞のタイプのセット $\Sigma$, 出発 点の細胞を表す $\omega$, 細胞の書き換え規則Pの 3 つである.す なわち $(\Sigma, \omega, \mathrm{P})$ で定義されるシステムがL S であり，こ の 3 つが基本パラメータといえる.

2. 1. 2 テーブルL S

テーブルL S とは, 細胞は始め規則 $\mathrm{P}_{1}$ に従って增殖を綝り 返すが，ある時点で切り替えスイッチが做いて細胞が従う規 則は $\mathrm{P}_{2}$ へと切り替えられるとするものである.

2. 1. 3 礁事 L S

確率L S とは，1 つの細胞タイプに対し複数の書き換え規 則が与えられていて，1 つのステップで適用すべき書き換え 規則をその中からある確率をもって選ぶというものである.

\section{2 Lシステムの進化的手法}

複雑な形態も L S を用いると简単な発生規則によって表現 することができる. しかし目的とする形態を形成するために は, $(\Sigma, \omega, \mathrm{P})$ をうまく決定しなければならない,そこで $(\Sigma$, $\omega$, P)を図 1 のようにGAにコーディングすることにより, 細胞の書き換え規則や出発点細胞などを最適に決定する. こ の方法を進化的Lシステム(E L S) と呼んでいる.

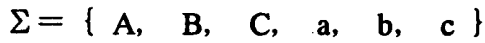

$$
\begin{aligned}
& \omega=\{\mathbf{X}\} \\
& \mathrm{P}=1
\end{aligned}
$$

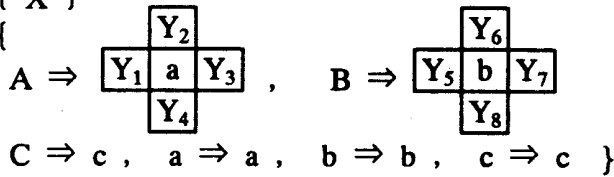$$
\begin{array}{llllll}
X & Y_{1} & Y_{2} & Y_{3} & \cdots & Y_{8}
\end{array}
$$

Chromosome of the GA

\section{3. 標造最道化問題への応用}

\section{1 問題}

集中荷重を受ける平板の板厚分布最適化問題を E L S を用 いて解く. 本問題は図 2 に示す 1 辺が固定された $100 \times$ $100[\mathrm{~mm}]$ の正方平板に荷重が作用しているとき, この平板に発 生する応力を材料の許容応力以下にとどめながら，その重量 を最小とする板厚分布を求めるものである．具体的には平板 を $10 \times 10$ 要素に分割し, 分割された各要素の状態を 1 ,

$10[\mathrm{~mm}]$ の 2 種類の板厚から選択することにより平板の板厚 分布を決定する. したがって本問題は次のように示される.

$$
\begin{aligned}
& \text { 設計変数 } t_{i j}(i, j=1,2, \cdots, 10) \quad \cdots \quad \text { (1) } \\
& \text { 目的関数 } W \rightarrow \min \quad \cdots \quad \text { (2) } \\
& \text { 制約条件 } \left.\begin{array}{l}
\sigma_{i j}<\sigma_{a} \\
t_{i j}=(1[\mathrm{~mm}], 10[\mathrm{~mm}])
\end{array}\right\}
\end{aligned}
$$

ここで, $\mathrm{t}_{\mathrm{ij}}$ : 要素の板厚, $\mathrm{W}$ : 平板の重量, $\sigma_{\mathrm{ij}}$ : 要素に発生 する応力, $\sigma \mathrm{a}:$ 材料の許容応力である.

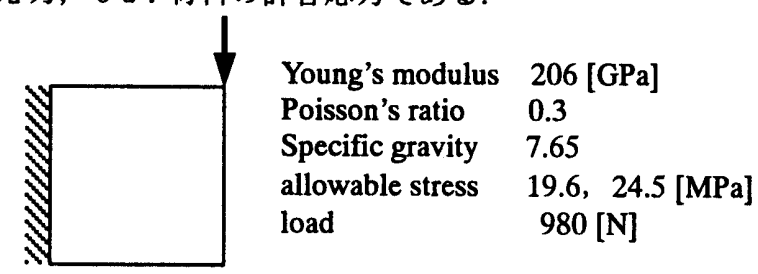

Fig.2 Analytical model

\section{2 E L Sによろ解の探索}

E L S では分割された各要素を細胞とみなし，出発点に設 定された細胞から增殖を繰り返して平板の板厚分布を創生す る.ここではE L S Sパラメータを様々に変えることで得ら れる解にどのような影霎が生ずるのかを調べる.

3. 2. 1 シンブルL S (S L S)

表 1,2 に出発点細胞位掼を荷重点に固定し, 細胞夕イプの

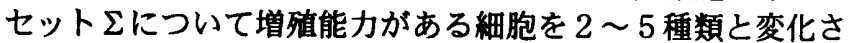
せた時の結果を示す.

Table1 Analytical results (allowable stress 19.6MPa)

\begin{tabular}{|c|c|c|c|}
\hline \multirow{2}{*}{ cell type } & \multirow{2}{*}{ Bit number of GA } & \multicolumn{2}{|c|}{ Analytical results } \\
\cline { 3 - 4 } & & Weight [g] & Generation \\
\hline 2 & 16 & 765 & 1 \\
\hline 3 & 36 & 413 & 43 \\
\hline 4 & 48 & 324 & 64 \\
\hline 5 & 60 & 289 & 41 \\
\hline
\end{tabular}

Table2 Analytical results (allowable stress 24.5MPa)

\begin{tabular}{|c|c|c|c|}
\hline \multirow{2}{*}{ cell type } & \multirow{2}{*}{ Bit number of GA } & \multicolumn{2}{|c|}{ Analytical results } \\
\cline { 3 - 4 } & & Weight [g] & Generation \\
\hline 2 & 16 & 765 & 1 \\
\hline 3 & 36 & 413 & 39 \\
\hline 4 & 48 & 269 & 63 \\
\hline 5 & 60 & 227 & 21 \\
\hline
\end{tabular}

Fig.1 prototype of the ELS

日本機械学会 [No.027-1] 北陸信越支部 第39期総会・講演会論文集 [’02.3.8, 石川県野々市町 $]$ 


\section{2.2 出哞点細胞位置をコーティング $(\mathrm{GA})$}

表 3,4 に細胞の書き換え規則に加え出発点細胞位置も G A にコーディングし， $\Sigma$ 前項と同じょうに変化させたときの 結果を示す.

Table3 Analytical results (allowable stress 19.6MPa)

\begin{tabular}{|c|c|c|c|}
\hline \multirow{2}{*}{ cell type } & \multirow{2}{*}{ Bit number of GA } & \multicolumn{2}{|c|}{ Analytical results } \\
\cline { 3 - 4 } & & Weight [g] & Generation \\
\hline 2 & 23 & 345 & 147 \\
\hline 3 & 44 & 331 & 69 \\
\hline 4 & 56 & 358 & 174 \\
\hline 5 & 68 & 276 & 64 \\
\hline
\end{tabular}

Table4 Analytical results (allowable stress 24.5MPa)

\begin{tabular}{|c|c|c|c|}
\hline \multirow{2}{*}{ cell type } & \multirow{2}{*}{ Bit number of GA } & \multicolumn{2}{|c|}{ Analytical results } \\
\cline { 3 - 4 } & & Weight [g] & Generation \\
\hline 2 & 23 & 310 & 113 \\
\hline 3 & 44 & 296 & 98 \\
\hline 4 & 56 & 234 & 254 \\
\hline 5 & 68 & 234 & 147 \\
\hline
\end{tabular}

\section{2. 3 テーブルL Sを使用(T L S)}

表 5,6 に基本的な L システムにテーブル L S を併用したと きの結果を示す.

Table5 Analytical results (allowable stress 19.6MPa)

\begin{tabular}{|c|c|c|c|}
\hline \multirow{2}{*}{ cell type } & \multirow{2}{*}{ Bit number of GA } & \multicolumn{2}{|c|}{ Analytical results } \\
\cline { 3 - 4 } & & Weight [g] & Generation \\
\hline 2 & 36 & 448 & 137 \\
\hline 3 & 76 & 379 & 224 \\
\hline 4 & 100 & 345 & 229 \\
\hline 5 & 124 & 262 & 120 \\
\hline
\end{tabular}

Table6 Analytical results (allowable stress 24.5MPa)

\begin{tabular}{|c|c|c|c|}
\hline \multirow{2}{*}{ cell type } & \multirow{2}{*}{ Bit number of GA } & \multicolumn{2}{|c|}{ Analytical results } \\
\cline { 3 - 4 } & & Weight [g] & Generation \\
\hline 2 & 36 & 310 & 54 \\
\hline 3 & 76 & 372 & 112 \\
\hline 4 & 100 & 324 & 170 \\
\hline 5 & 124 & 221 & 157 \\
\hline
\end{tabular}

表 7,8 に基本的な L システムにテーブル L S および出発点 細胞位置も変化させたときの結果を示す.

Table7 Analytical results (allowable stress 19.6MPa)

\begin{tabular}{|c|c|c|c|}
\hline \multirow{2}{*}{ cell type } & \multirow{2}{*}{ Bit number of GA } & \multicolumn{2}{|c|}{ Analytical results } \\
\cline { 3 - 4 } & & Weight [g] & Generation \\
\hline 2 & 43 & 255 & 74 \\
\hline 3 & 84 & 289 & 199 \\
\hline 4 & 108 & 276 & 120 \\
\hline 5 & 132 & 269 & 183 \\
\hline
\end{tabular}

Table8 Analytical results (allowable stress 24.5MPa)

\begin{tabular}{|c|c|c|c|}
\hline \multirow{2}{*}{ cell type } & \multirow{2}{*}{ Bit number of GA } & \multicolumn{2}{|c|}{ Analytical results } \\
\cline { 3 - 4 } & & Weight [g] & Generation \\
\hline 2 & 43 & 255 & 306 \\
\hline 3 & 84 & 248 & 337 \\
\hline 4 & 108 & 221 & 31 \\
\hline 5 & 132 & 227 & 202 \\
\hline
\end{tabular}

\section{2. 4 磁事 L S を使用}

表 9，10 確率L S を使用し，細胞の書き換え規則を $2 ， 3$ 通りとしたときに得られる解にどのような影辢を与えるかを 示す.

Table9 Analytical results (allowable stress 19.6MPa)

\begin{tabular}{|c|c|c|c|}
\hline \multirow{2}{*}{$\begin{array}{l}\text { Rule of cell } \\
\text { rewrite }\end{array}$} & \multirow{2}{*}{$\begin{array}{c}\text { Bit number of } \\
\text { GA }\end{array}$} & \multicolumn{2}{|c|}{ Analytical results } \\
\hline & & Weight [g] & Generation \\
\hline 2 & 36 & 255 & 32 \\
\hline 3 & 54 & 255 & 106 \\
\hline
\end{tabular}

Table10 Analytical results (allowable stress 24.5MPa)

\begin{tabular}{|c|c|c|c|}
\hline $\begin{array}{c}\text { Rule of cell } \\
\text { rewrite }\end{array}$ & $\begin{array}{c}\text { Bit number of } \\
\text { GA }\end{array}$ & \multicolumn{2}{|c|}{ Analytical results } \\
\cline { 3 - 4 } & 36 & Weight $[\mathrm{g}]$ & Generation \\
\hline 2 & 531 & 88 \\
\hline 3 & 54 & 227 & 38 \\
\hline
\end{tabular}

\section{3 考察}

図 3 に各パラメータごとの重量と解の得られた G A世代の 関係を示す，図から明らかなように，いずれのパラメータに おいても細胞タイプのセットを増やすことで, 得られた形状 は軽くなっている．これは細胞タイプのセットが増えること により，L システムにより表現できる形状が複雑になり得る ためである．また，細胞タイプのセットを增やすことで解が 得られた G A世代が大きくなるが，ある程度セット数を増や すと逆に早く解を得ることができる傾向にある.これはセッ 卜数を大きく取ることで, 同じ形状を得るための成長規則の 自由度が増すためであると考えられる。

得られる解については，3つの基本パラメータのみで表現 したシンプルL Sよりも, テーブル L S を使用することや, 出発点細胞位置を G Aにコーディングし決定することでよい 解を得ることができる. またテーブル L S と出発点細胞位置 コーディングを併用することで細胞タイプのセットが少なく てもよい解を得やすいことがわかる.これはシンプルL S で は表せないような複雑な構造を得ることができるためである.

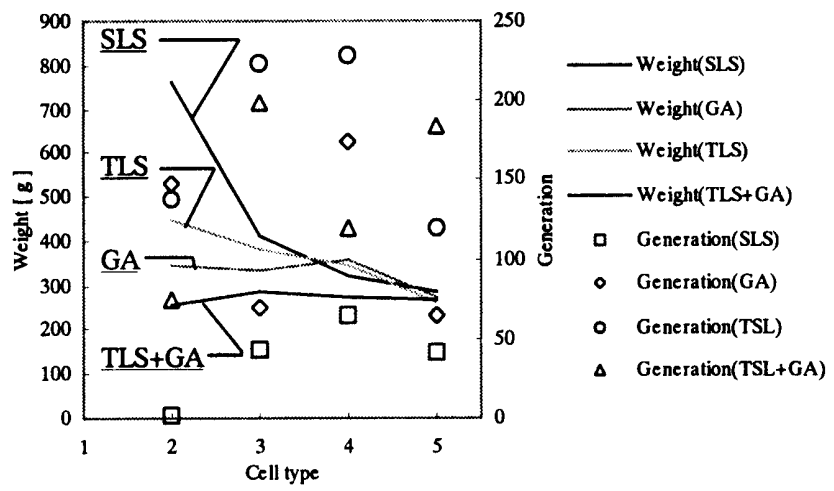

Fig. 3 Effect of cell type on weight and generation

\section{4. 結言}

今回の解析において E L S を用いて目的に応じた最適構造 を効率的に得るには細胞タイプのセットを増やすことが最も 重要であることが明らかとなった．そしてテーブル L S を使 用することや, 出発点細胞位置を G Aの染色体にコーティン グすることが複雑な構造を得るために必要であることも明ら かとなった.

\section{参孝文献}

（1）尾田十八, Sourav Kundu, 齊藤誠, 日本機械学会論文集,

$\mathrm{A}$ 編, 67 巻, 653 号, $(2001-1)$, p. 121-126

（2）土居洋文, 生物のかたちづくり，(1988)，55, サイエンス社 